\title{
The Influence of Selected Meteorological Factors on Microbial Biomass and Mineralization of Two Organic Fertilizers
}

\author{
Mignon S. SANDOR ${ }^{1}$, Traian BRAD², Aurel MAXIM ${ }^{1}$, Constantin TOADER ${ }^{1}$ \\ ${ }^{1}$ University of Agricultural Sciences and Veterinary Medicine, Cluj-Napoca, 3-5 Mănăştur, \\ 400372 Cluj-Napoca, Romania; sandormignon@yahoo.com \\ ${ }^{2}$ Institute of Speleology Emil Racovita, 5 Clinicilor, 400006 Cluj-Napoca, Romania
}

\begin{abstract}
A mesocosm study was conducted in order to evaluate the effects of short-term rainfall and temperature variation on soil microbial biomass and bacteria to fungi ratio. In addition, the relation between the decomposition process of two organic fertilizers, cattle manure and barley straw, and the activity of soil microbial biomass was also studied. In order to assess the effect of biological activity on soil fertility the dynamics of soil $\mathrm{pH}, \mathrm{N}-\mathrm{NO}_{3}, \mathrm{~N}-\mathrm{NH}_{4}^{+}, \mathrm{C}_{\text {org }}$ and $\mathrm{N}_{\mathrm{t}}$ during plant growing season was measured. The results suggest that shortterm variation of climate had a significant effect on microbial biomass with dry periods distinguished by a reduced microbial biomass compared to wet periods. The ratio bacteria to fungi seems also to be sensitive to variations in rainfall and temperature regime, however further studies are required to draw a definitive conclusion. Regarding the type of fertilizer used, the straw treatments showed higher microbial biomass than the manure treatments, but higher decomposition rate was observed in manure fertilized soil. The effect of soil biological activity on soil $\mathrm{pH}$ was limited for both manure and straw treatments while the changes of the soil nitrate amounts are related to the microbial biomass. The study indicates that nitrate immobilization and mineralization processes are influenced by meteorological conditions and microbial biomass dynamics. In contrast, soil organic carbon and total nitrogen did not seem to be affected by variations in temperature, rainfall and microbial activity.
\end{abstract}

Keywords: barley straw, cattle manure, meteorological factors, microbial biomass, mineralization

\section{Introduction}

The use of organic fertilizers is an agricultural practice that aims to maintain and increase soil fertility in order to achieve agroecosystems sustainability with minimal financial and environmental costs. The most used organic fertilizers are cattle manure and organic residues (Stark et al., 2004). These organic resources are either incorporated in the soil or applied to the soil surface and following decomposition will provide an important nutrient source for plants. The organic matter decomposition involves two simultaneous and complementary processes, the mineralization and humification (Lavelle and Spain, 2004). Mineralization is a catabolic process where the decomposing microorganisms transform the organic compounds into inorganic forms like nitrates, phosphates, sulfates and others. Among the decomposers, soil bacteria and fungi are considered to be a key functional group in mineralization (Swift et al., 2004).

One of the most popular methods of assessing the importance of soil microflora in decomposition processes is the measurement of the microbial biomass as a whole (Brookes, 2001). Direct microscope counting, plate count techniques, chloroform fumigation incubation, chloroform fumigation extraction, substrate induced respiration, ATP extraction, total extractable phospholipid fatty acids, or DNA extraction and determination are a diverse range of techniques employed to estimate soil microbial biomass. Among these methods, the substrate induced respiration is recommended to be a simple one which allows the measurements of the total microbial biomass as well as the estimation of bacteria:fungi ratio in soil (Anderson and Domsch, 1978).

Beside representing the main driving force behind the decomposition process, soil microbial biomass can also be an important nutrient source either directly as prey for larger organisms (e.g. protozoa or invertebrates), or indirectly through biomass recycling processes. The soil microbial biomass is largely composed of bacteria and fungi and the two components respond quantitatively different to agricultural management (Bardgett et al., 1996). Bacteria and fungi have different carbon to nitrogen ratio in their body and consequently changes of bacteria:fungi ratio can lead to the immobilizations or availability of nitrogen in soils (Bittman et al., 2005). Soil microbial community is dominated by inactive forms (Heinemeyer et al., 1999), which under favorable conditions can become active and make nutrients available to plants as a result of the decomposition.

In arable fields microclimate, the quantity and quality of available organic substrate are major factors that 
108

influence the growth of microbial biomass (Mamilov and Dilly, 2002). The effects of organic fertilizers application on microbial biomass is well documented (Govaerts et al., 2007; Bittman et al., 2005), while still little is known on bacteria:fungi ratio in relation to organic fertilization of agricultural soils (Bardget et al., 1996). The influence of the climatic regime on microbial biomass and activity is generally established (Insam et al., 1989; Insam, 1990), however, short-term climate variation on microbial biomass and bacteria to fungi ratio is still little understood.

The present study aims at investigated the dynamics of microbial biomass and bacteria:fungi ratio during a growing season in the presence of two types of organic fertilizers, cattle manure and barley straw. We also followed the short-term effects of precipitations and temperature on microbial biomass with respect to their impact on soil fertility parameters.

\section{Materials and methods}

The experiments were conducted in 34 liters PVC pots fixed in $40 \mathrm{~cm}$ deep ditches. The pots were filled with soil to a bulk density of $1.25 \mathrm{~g} / \mathrm{cm}^{3}$. The soil used for the study was a luvic phaeozem (clay 52\%, silt 18\%, sand 30\%) with a $\mathrm{pH}$ (in water) of 7.44 , organic carbon content of $3.77 \%$ and total nitrogen of $0.29 \%$. Top soil (up to $20 \mathrm{~cm}$ ) was collected from a field where sugar beet was previously cultivated without the addition of any fertilizers and sieved (4 $\mathrm{mm}$ mesh size) in order to remove larger materials such as smaller stones and larger organic matter. To eliminate the existing fauna the soil was then frozen to $-12^{\circ} \mathrm{C}$ and kept for 20 days in extremely dry conditions. Approximately $42.5 \mathrm{~kg}$ of soil was added to each pot and the soil moisture was adjusted to $20 \%$ of the soil water holding capacity. The experimental pots were then left to rest for 5 days to allow the recovery of soil microflora which was inactive during the freezing and drying period.

After the 5-days period the organic amendments, the cattle manure and barley straw, were added to the corresponding treatments. The length of straw was between 2.5 $-4.0 \mathrm{~cm}$, the content of $\mathrm{C}_{\text {org }}$ was $42.9 \%$ and the total nitrogen $\left(\mathrm{N}_{\mathrm{t}}\right)$ represented $0.925 \%$ of the total straws weight. The amount of straw applied to each pot was about $150 \mathrm{~g}$, half of it was mixed with the soil while the other half was uniformly distributed on the soil surface. The organic carbon of cattle manure was $36.9 \%$, while the nitrogen content was $2.4 \%$. As with the straw amendments, $150 \mathrm{~g}$ of manure was added to the pots, but only $30 \mathrm{~g}$ were distributed on the soil surface while the rest was mixed with the soil. Each treatment was replicated three times. Each pot was seeded with 70 barley seeds to obtain the soil rhizosphere effect. The pots were then covered with a plastic net $(1-\mathrm{mm}$ mesh size) to prevent the contamination with other organic materials or the access of animals to the pots.

The treatments were placed in natural conditions from the start of the experiment in April, until the end of it in
October. During this period approximately $150 \mathrm{~g}$ of soil were collected from the top $15 \mathrm{~cm}$ of the soil in May, June, August and October using a cylindrical sampler $(7 \mathrm{~mm}$ in diameter). After each sampling date the organic matter extracted together with the soil was separated from soil and reintroduced into the mesocosms. From the soil samples $10 \mathrm{~g}$ were designated to $\mathrm{pH}$ measurements, dried at room temperature, mortared and kept in paper bags until the measurements was done. In order to measure the soil organic carbon and total nitrogen, $10 \mathrm{~g}$ of soil were quickly dried to $100^{\circ} \mathrm{C}$ and then kept in plastic containers at room temperature. For nitrate and ammonium measurements 50 $\mathrm{g}$ of soil was kept frozen until the analysis was performed and, finally, $70 \mathrm{~g}$ of soil were kept at $4^{\circ} \mathrm{C}$ for microbial biomass and bacteria:fungi ratio measurement.

At the end of the experiment, the straw and manure present on soil surface of the pots was collected and dried at $50^{\circ} \mathrm{C}$ overnight and then weighted. The amount of straw mixed with soil and not decomposed was also determined by removing the first $15 \mathrm{~cm}$ of soil from the pots and washing it under a jet of water through a $4 \mathrm{~mm}$ and $2 \mathrm{~mm}$ mesh sized sieves. The collected straw was dried and weighted. For the cattle manure treatments this procedure was no longer possible because all the manure mixed with the soil at the beginning of the experiment was decomposed.

The soil $\mathrm{pH}$ was measured electrochemically after extraction with $0.01 \mathrm{M} \mathrm{CaCl}_{2}$ using a $\mathrm{pH}$ meter instrument WTW inoLab pH 720. The soil ammonium and nitrates were determined by colorimetry, after extraction in 0.0125 $\mathrm{M} \mathrm{CaCl}_{2}$, using a segmented flux analyzer Skalar SANplus. The organic carbon and total soil nitrogen were measured by dry combustion using the automated analyzer LECO TruSpec CN.

Soil microbial biomass and bacteria:fungi ratio was measured using the substrate induced respiration method (Anderson and Domsch, 1978). For this, $10 \mathrm{~g}$ of soil (dry weight) was sieved through a $2 \mathrm{~mm}$ sieve and mixed with glucose, which is an easily metabolized substrate. The method uses also two inhibitors, i.e. the streptomycin for bacteria and cycloheximide for fungi, in order to estimate the bacteria to fungi ratio. The two inhibitors were added separately to the soil sample (soil/glucose/streptomycin and soil/glucose/cycloheximide mixtures) and also mixed together with soil (soil/glucose/streptomycin/cycloheximide). The amounts of reagents per soil samples were $8000 \mathrm{ppm}$ glucose, $4000 \mathrm{ppm}$ streptomycin and 6000 ppm cycloheximide. The produced $\mathrm{CO}_{2}$ concentration was measured after 1 hour from the addition of the substrates until the $\mathrm{CO}_{2}$ values remained constant. The mean value of $\mathrm{CO}_{2}$ obtained for the soil mixed with glucose was used to estimate the microbial biomass with the formula $x=40.4 y+0.37$ (Anderson and Domsch, 1978), where $x$ is the microbial biomass in $\mu \mathrm{g} \mathrm{C} / \mathrm{g} \mathrm{sol}$, and $y$ is the mean initial production of $\mathrm{CO}_{2}$ measured in $\mathrm{ml} \mathrm{CO} / \mathrm{g}$ soil/ hour. The $\mathrm{CO}_{2}$ produced in the soil/streptomycin/cycloheximide samples was used to measure bacteria:fungi ra- 
tio. The estimation of bacterial biomass was made according to the formula:

Bacterial biomass $(\%)=(A-B) /(A-D) \times 100$, la:

while fungal biomass was calculated using the formu-

Fungal biomass $(\%)=(\mathrm{A}-\mathrm{C}) /(\mathrm{A}-\mathrm{D}) \times 100$,

where A represents the $\mathrm{CO}_{2}$ amount that was produced in the soil/glucose samples, $\mathrm{B}$ is the $\mathrm{CO}_{2}$ amount that was produced in the soil/glucose/streptomycin samples, C is the $\mathrm{CO}_{2}$ produced in the soil/glucose/cycloheximide samples and $\mathrm{D}$ is the $\mathrm{CO}_{2}$ produced in the soil/glucose/ streptomycin/ cycloheximide samples.

The climatic data were obtained from the meteorological station of the University of Agricultural Science and Veterinary Medicine in Cluj-Napoca, which was located $100 \mathrm{~m}$ away from the experimental place. For this study a direct relationship between rainfall and soil moisture as well as between air and soil temperature was considered. Data regarding air temperature, soil temperature and precipitations were processed and interpreted according to the method of Criveanu (2004).

The results were analyzed using SPSS.11 (SPSS Inc., Chicago, Illinois). ANOVA was used to test the effect of independent variable (type of organic matter and sampling time) on soil parameters ( $\mathrm{pH}, \mathrm{N}^{-\mathrm{NO}_{3}}, \mathrm{~N}_{-} \mathrm{NH}_{4}^{+}, \mathrm{C}_{\mathrm{org}}, \mathrm{N}_{\mathrm{t}}$ and microbial biomass). Tukey test was used to compare the mean differences of tested parameters between sampling dates while $t$ test was used to compare the means differences between treatments at the same sampling time.

\section{Results and discussion}

\section{Weather conditions}

The temperature and precipitations are two climatic factors known to have a great influence on the soil biological processes and the weather records obtained indicate the experimental year as a dry year with temperature values over the normal thresholds (Tab. 1). These parameters are usually positively correlated with the decomposition rates and negatively with the microbial biomass (Insam $e t$ al., 1989). Likewise, as Manilov and Dilly (2002) pointed out, the long and short-term changes of soil temperature and humidity affect the decomposition rates through their influence on microbial growth and activity. The global climate change processes can lead to a more extreme climate regime with significant changes in the structure of soil biological community and activity (Sticht et al., 2006). The experimental year was characterized by extreme weather parameters, especially high temperature and lack of precipitations, parameters that had a severe impact on microbial biomass, bacteria:fungi ration and soil fertility status.

\section{Decomposition rate}

The decomposition rate of the organic fertilizers used thought the experiment was expressed in percent decomposed organic matter from the initial amount (Tab. 2).
Tab. 1. Recorded rainfall and temperature during experiment and their differences to multiyear averages

\begin{tabular}{ccccc}
\hline Month & $\begin{array}{c}\text { Monthly } \\
\text { precipitations } \\
\left(\mathrm{mm} / \mathrm{m}^{2}\right)\end{array}$ & $\begin{array}{c}\text { Differences } \\
\text { compared } \\
\text { to normal }\end{array}$ & $\begin{array}{c}\text { Averages } \\
\text { temperature } \\
\left({ }^{\circ} \mathrm{C}\right)\end{array}$ & $\begin{array}{c}\text { Differences } \\
\text { compared } \\
\text { to normal }\end{array}$ \\
\hline April & 16.6 & -30.4 & 15.20 & +5.50 \\
May & 58.2 & -18.1 & 20.40 & +6.10 \\
June & 50.2 & $-40,2$ & 25.50 & +8.00 \\
July & 69.1 & -13.1 & 26.03 & +6.73 \\
October & 33.0 & -8.50 & 13.40 & +4.30 \\
\hline
\end{tabular}

The decomposition process developed differently for the straw and cattle manure treatments. In the case of cattle manure the entire amount added to the soil was decomposed, while only $45 \%$ of the manure added on the soil surface was decomposed. For barley straw $63.6 \%$ was decomposed into the soil, while only $51 \%$ was decomposed at the soil surface. This is a result of the differences in chemical composition of the two types of organic fertilizers and the local climate conditions. The cattle manure has a lower $\mathrm{C}: \mathrm{N}$ ratio $(\mathrm{C}: \mathrm{N}=15)$ than barley straws $(\mathrm{C}: \mathrm{N}$ = 46) making manure more available for soil microflora. This is in agreement with previous studies that also found an increase in microbial biomass, metabolic activity and mineralization when cattle manure was used as fertilizer (Bittman et al., 2005; Elfstrand et al., 2007).

A possible explanation for the observed results is that straw contains recalcitrant chemical compounds that are difficult to decompose and are less available for soil microflora (Sandor and Schrader, 2007). However, straw can become an important nutrient for microflora in time, when they are partly degraded by the fungi and soil fauna. In our study, the decomposition rate of manure was more intense at the beginning of the experiment, while straw decomposed more intensely toward the end of the experiment. Also the decomposition rate was more intense in the soil than at the surface because of increased moisture which offer better conditions for microbial activity. An increase in mineralization rate was also observed in soils subjected to drying-rewetting cycles (Manilov and Dilly, 2002). During the experiment, our mesocosms were also subjected to several natural drying-rewetting cycles and this could also explain the high rate of organic fertilizers decomposition.

\section{Chemical parameters}

The analysis of variance revealed the influence of the organic matter type on microbial biomass and $\mathrm{pH}$, while sampling time was determinant for microbial biomass, $\mathrm{pH}, \mathrm{N}-\mathrm{NO}_{3}, \mathrm{~N}_{-} \mathrm{NH}_{4}^{+}$and $\mathrm{N}_{\mathrm{t}}$. The combined effect of the two factors had a significant influence on microbial biomass and $\mathrm{pH}$ (Tab. 3).

Although the effect of the type of organic matter and sampling time on the $\mathrm{pH}$ is statistically significant the amplitude differences of $\mathrm{pH}$ values are not very high. Even if fungi prefers more acid soil than bacteria, both bacteria 
Tab. 2. Decomposition rate of the two organic fertilizers used in the study (mean \pm SD)

\begin{tabular}{ccccccc}
\hline & \multicolumn{3}{c}{ Straw } & & \multicolumn{2}{c}{ Manure } \\
\hline Organic matter & $\begin{array}{c}\text { Initial amount } \\
\text { (g dry matter) }\end{array}$ & $\begin{array}{c}\text { Final amount } \\
\text { (gdry matter) }\end{array}$ & $\begin{array}{c}\text { Decomposed } \\
(\%)\end{array}$ & $\begin{array}{c}\text { Initial amount } \\
\text { (g dry matter) }\end{array}$ & $\begin{array}{c}\text { Final amount } \\
(\mathrm{g} \text { dry matter })\end{array}$ & $\begin{array}{c}\text { Decomposed } \\
(\%)\end{array}$ \\
\hline Mixed with soil & 75 & $27.3 \pm 5.02$ & 63.6 & 32.4 & 0 & 100 \\
Placed on the soil surface & 75 & $36.7 \pm 5.1$ & 51.07 & 8.1 & $3.65 \pm 1.1$ & 45.6 \\
\hline
\end{tabular}

and fungi grow well at a slightly alkaline $\mathrm{pH}$, so that $\mathrm{pH}$ was not a limiting factor for microbial biomass development and metabolic activity. The $\mathrm{pH}$ was always higher for cattle manure treatments then in barley straw treatments (Fig. 1). This result can be explained by an input of alkaline compounds, the organic-mineral complexation of aluminum ions and by an essential input of buffering compounds added to the soil together with cattle manure (Rusu et al., 1970).

The dynamics of nitrates in mesocosms was relatively similar regardless the type of added organic fertilizer. We only registered significant differences in October $(t=2.71$, $\mathrm{P}=0.042$ ) when the amount of nitrates was higher in barley straw treatments than in cattle manure treatments (Fig. 1). The sampling time has a more significant influence on nitrates (Tab. 3). A significant decrease in nitrates concentration was observed in May compared to the amount measured in April for both cattle manure and barley straw treatments (Fig. 1). The decrease of soil nitrates amount continued also in June when we obtained lower values to those measured in May in both, cattle manure and barley straw treatments (Fig. 1). There was no significant difference between nitrate levels measured in June and July for barley straw treatments. For cattle manure treatments, nitrates concentration was lower in July then in June. A significant increase of soil nitrates was observed in straw treatments from July to October (Fig. 1). The dynamics of nitrates relates closely to the physico-chemical properties of the soil, the climatic conditions and the soil biological community (Azam and Farooq, 2003). In the study the severe decrease of nitrates immediately after the start of the experiment was most probably due to the absorption processes performed by plant roots. During this period (JuneJuly) the plants developed well and the nitrates were, probably, their main nitrogen source. They were absorbed from the soil and assimilated into the plants biomass. The mi-

Tab. 3. F values and levels of significance (ANOVA) for each factor (organic matter type and sampling time) and each dependent variable (soil parameters)

\begin{tabular}{ccccccc}
\hline Factor & $\mathrm{pH}$ & $\mathrm{N}^{-\mathrm{NO}_{3}}$ & $\mathrm{~N}_{-\mathrm{NH}_{4}^{+}}$ & $\mathrm{C}_{\text {org }}$ & $\mathrm{Nt}$ & $\begin{array}{c}\text { Microbial } \\
\text { biomass }\end{array}$ \\
\hline OM type & $214^{*}$ & 0.03 & 0.15 & 0.11 & 1.33 & $23.5^{*}$ \\
Sampling time & $38.8^{*}$ & $154.8^{*}$ & $120.5^{*}$ & 2.20 & $5.1^{*}$ & $20.6^{*}$ \\
OMtype ${ }^{*}$ time & $15^{*}$ & 0.76 & 0.82 & 0.34 & 0.29 & $3.46^{*}$ \\
$\mathrm{R}^{2}$ & 0.87 & 0.91 & 0.89 & 0.20 & 0.23 & 0.65 \\
\hline
\end{tabular}

Note: ${ }^{*}$ indicate significant level at $\mathrm{P}<0.05$ crobial biomass was higher in May than in April and this can suggest an immobilization of nitrogen in microbial biomass. Moreover, a period of rains was registered during April and May when Sandor et al. (2009) reported high amount of nitrates in collected soil leachate.

The decrease of soil nitrates during May-June period could also be the result of leaching process. During this interval, the climatic conditions with high temperature and lack of precipitations were unfavorable to biotic activity. This type of conditions usually inhibits nitrification and hence the availability of nitrates (Montagnini, 1989).

During October the temperature decreased while the amount of precipitations increased. Under such conditions soil biological activity was stimulated, including nitrification, and therefore the amount of soil nitrates increased.

A slight increase of soil ammonium concentration was recorded during the experiment in both treatments, without significant differences between cattle manure and barley straw treatments at any sampling dates. Similar to nitrate, the dynamics of ammonium revealed significant differences when different sampling time are considered for both cattle manure and straw treatments. The concentration of ammonium in soil was significantly higher in May compared to that in April in the case of cattle manure treatment (Fig. 1). The amount of ammonium was also higher in June than in May for both cattle manure and barley straw treatments (Fig. 1). No significant differences were registered between the ammonium concentrations obtained in July compared to those measured in June for cattle manure and barley straw treatments. A significant increase of ammonium concentration was registered in October compared to July for barley straw treatments. The increase of ammonium concentration in time could be the result of the smaller roots absorption process while the plants pass to the maturity stage. It can also be the result of the decreasing nitrification activity during summer. Another source of soil ammonium can be the fungal cell content which is released into soil after fungal cell lyses (Manilov et al., 2001). The microbial biomass from our mesocosms was dominated by the fungi and those the lyses of fungal cells due to climate conditions or predation can also lead to soil ammonium release. The organic carbon and total nitrogen were relatively constant during experiment. It is already known that organic carbon and total nitrogen concentrations remain relatively constant in time and they only slightly modify as a result of fertilization. Stark $e t$ al. 

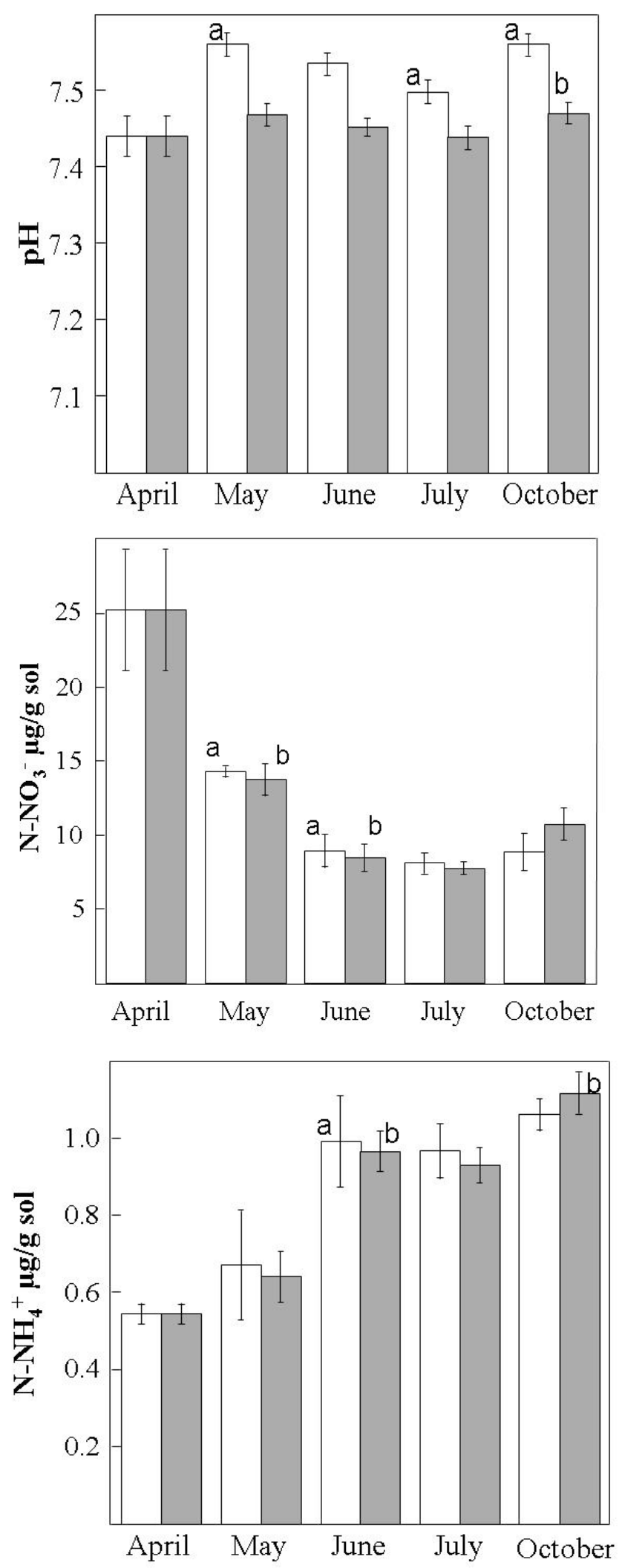

Fig. 1. Dynamics of $\mathrm{pH}, \mathrm{N}-\mathrm{NO}_{3}{ }^{-}$and $\mathrm{N}_{-} \mathrm{NH}_{4}^{+}$during experiment (white columns - manure treatments, grey columns - straw treatments). Letters indicate significant differences (Tukey test) between means of consecutive sample ( $\mathrm{a}$ - manure treatments and $\mathrm{b}$ - straw treatments). Bars represent standard deviations
(2007) pointed that organic carbon and total nitrogen are not affected by short-term agricultural practices.

\section{Dynamics of microbial biomass and bacteria:fungi ratio}

The microbial biomass was influenced by the type of fertilizer used and by the sampling time (Tab. 3). The microbial biomass was always higher in barley straw treatments than in cattle manure treatments. The differences were significant in May $(\mathrm{t}=4.95, \mathrm{P}=0.004)$, June $(\mathrm{t}=$ 12.3, $\mathrm{P}<0.01)$ and October $(\mathrm{t}=3.06, \mathrm{P}=0.028)$. These results come in contradiction to other studies, where microbial biomass increased more in the presence of cattle manure than in the presence of straw or other organic materials (Flißbach and Mäder, 2000; Bittman et al., 2005). These studies were performed over shorter periods of time and the content of soil nitrogen was small. The results of present study indicated that nitrogen was not a limiting factor allowing the growth of microbial population. Fungi are mainly responsible for the decomposition of less-degradable organic compounds in straw, such as hemicellulose and cellulose. When high level of nitrogen is present in soil, fungi are able to produce more biomass per nitrogen unit than bacteria due to their higher carbon to nitrogen ratio (Manilov, 2002). In our experiment the bacteria:fungi ratio revealed the dominance of fungi. When straw were present fungi growth better then bacteria and therefore straw treatments supported larger biomass than cattle manure treatments (Fig. 2).

Considering microbial biomass dynamics in time an increase was observed from April to May in both cattle manure and barley straw treatments. This increase can be explained by the addition of fertilizers and favorable climate conditions (presence of water) during this period

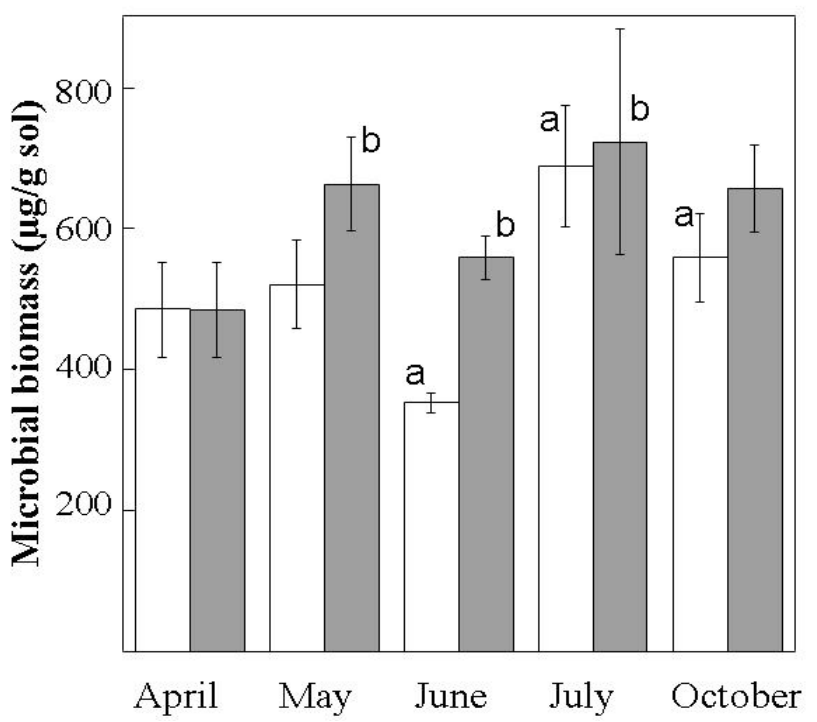

Fig. 2. Microbial biomass during experiment (white columnscattle manure treatment, grey columns-straw treatment). Letters indicate significant differences (Tukey test) between means of consecutive sample (a-manure treatments, b-straw treatments). Bars represent standard deviations 
112

(Fig. 2). Microbial biomass was smaller in June compared to that measured in May in both cattle manure and barley straw treatments (Fig. 2). This biomass loss was of $32 \%$ for cattle manure treatments and $15 \%$ for barley straw treatments and it could be due to the extreme climatic conditions, with high air temperature and lack of precipitations. This result is similar to that obtained by Insam (1990), who showed that during dry periods microbial biomass decreases and the decomposition of organic matter is slowing down. Likewise, Manilov and Dilly (2002) pointed that drying - rewetting period determined an inhibition of fungi growth and hence a reduction of total biomass. The decrease of microbial biomass observed in our experiment was less obvious in the straw treatment compared to the manure ones because the added straw prevented water loss and therefore maintained higher soil humidity.

In July we registered the largest microbial biomass values. These values were significantly higher than those measured in June for both cattle manure and barley straw treatments (Fig. 2). This increase was due to the favorable climate conditions with high level of precipitations, but also to an extra nutrients input originating from the dead microbial biomass observed before July.

The microbial biomass decreased in October compared to that obtained in July for both cattle manure and straw treatments.

The assessment of bacteria to fungi ratio revealed the fungal dominance throughout the experiment (Fig. 3). This ratio was higher in April than in May and it was also higher in July than in October in the case of cattle manure treatments. For barley straw treatments the ratio bacteria to fungi was higher in May than the one determined in June and it was also higher in July compared to that in June.

The dominance of fungi in mesocosms can be explained by the presence, especially in the straw treatments of cellu-

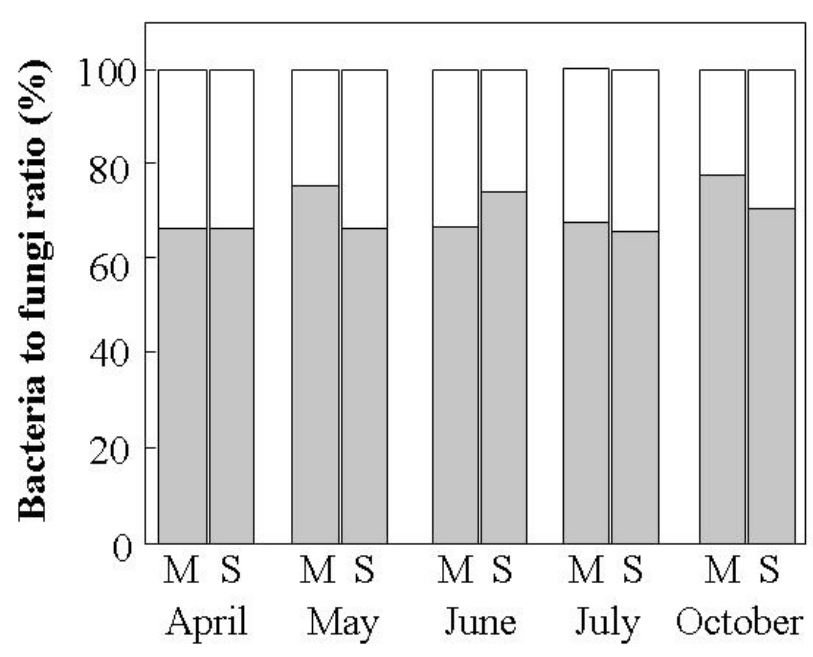

Fig. 3. Bacteria to fungi ratio during experiment. Grey bars represent the fungi and white bars are bacteria. M-cattle manure; S-Barley straws lose and hemicellulose compounds which are usually better degraded by fungi than by bacteria (Manilov, 2002). The short-term variation of this ratio is sometimes difficult to explain (Bittman et al., 2005). This variation can be due to the existing organic substrate, climatic conditions and biotic community. In present experiment this variation was mainly due to the climate conditions. The decrease of fungi biomass relates most probably to their high sensitivity to low soil humidity. Similar results were obtained by Gordon et al. (2008) who studied the effect of drying and rewetting processes on soil microbial community. They emphasized that fungi, which inhabit soil macropores or surface of macroaggregates, were more affected by drought than bacteria which inhabit soil micropores and microaggregates. In other studies (Griffiths et al., 2003) the soil bacterial populations are considered more resistant to low humidity due to their complex capacities of cell-activity regulation. The results presented in these studies could not be fully confirmed in present experiment. Changes of the bacteria to fungi ratio need to be studied during longer periods of time in order to obtain valuable results. In agroecosystems this type of research is needed for practical aspects, because the increase of bacterial biomass compared to fungal biomass can lead to immobilization of nitrogen, while a decrease of bacterial compared to fungi biomass will determine soil nitrogen availability (Bittman et al., 2005).

\section{Conclusions}

Changes of climate conditions during growing seasons of plants influenced microbial biomass and dynamics of soil nitrates and ammonium. Wet periods were associated with high values of microbial biomass while during dry periods low microbial biomass was measured. These changes could affect plant growth through mobilization or immobilization of soil nutrients. Straw fertilized soil supported higher microbial biomass than manure fertilized soil, but higher decomposition rate was registered in manure treatments. Changes in bacteria to fungi ratio during the experiment indicated a shift in microbial community structure, however more studies are needed to fully understand its dependence on weather and fertilization regime.

\section{Acknowledgements}

We are grateful for the financial support of the CNCSIS (PD project nr.183/2010) that enabled the preparation of this manuscript.

\section{References}

Anderson JPE, Domsch KH (1978). A physiological methods for the quantitative measurement of microbial biomass in soils. Soil biology and Biochemistry 10:215-221.

Azam F, Farooq S (2003). Nitrification Inhibition in Soil and Ecosystem Functioning-An Overview. Pakistan Jornal of 
Biological Science 6:528-535.

Bardgett RD, Hobbs PJ, Frostegard A (1996). Changes in soil fungal: bacterial biomass ratios following reductions in the intensity of management of an upland grassland. Biol Fertil Soils 22:261-264

Bittman S, Forge TA, Kowalenko CG (2005). Responses of the bacterial and fungal biomass in a grassland soil to multyyear applications of dairy manure slurry and fertilizer. Soil Biology and Biochemistry 37:613-623.

Brookes Ph (2001). The Soil Microbial Biomass: Concept, Measurement and Applications in Soil Ecosystem Research. Microbes and Environments 16(3):131-140.

Criveanu HR (2004). Agrometeorology-classic and modern, Ed. Digital Data, Cluj-Napoca, Romania (in Romanian).

Elfstrand S, Hedlund K, Martensson A (2007). Soil enzyme activities, microbial community composition and function after 47 years of continuous green manuring. Applied Soil Ecology 35:610-621.

Flißbach, A, Mäder P (2000). Microbial biomass and size-density fractions differ between soil of organic and conventional agricultural systems. Soil Biology and Biochemistry 32:757768.

Gordon H, Haygarth PhM, Bardget RD (2008). Drying and rewetting effects on soil microbial community composition and nutrient leaching. Soil Biology and Biochemistry 40:302-311.

Govaerts B, Mezzalama M, Unno Y, Sayre K, Luna-Guido M, Vanherck K, Dendooven L, Deckers J (2007). Influence of tillage, residue management, and crop rotation on soil microbial biomass and catabolic diversity. Applied Soil Ecology 37:8-30.

Griffiths RI, Whiteley AS, O’Donnell AG, Bailey MJ (2003). Physiological and community responses of established grassland bacterial populations to water stress. Applied and Environmental Microbiology 69 (12):6961-6968.

Heinemeyer O, Höper H, Kleefisch B, Blagodatski S (1999). Differentiation of the active and dormant microbial biomass in soil by respirometry tests. Mitteinlungen der Deutschen Bodenkundlichen Gesellschaft 91:626-629 (in German).

Insam H, Parkinson D, Domsch KH (1989). Influence of macroclimate on soil microbial biomass. Soil Biology and Biochemistry 21(2):211-221.

Insam H (1990). Are the soil microbial biomass and basal respiration governed by the climatic regime? Soil Biology and Biochemistry 22(4):525-532.
113

Lavelle P, Spain A (2005). Soil Ecology. Springer Publisher, Dordrecht, The Netherlands.

Manilov AS, Byyov BA, Zvyagintsev DZ, Dilly OM (2001). Predation and fungal and bacterial biomass in a soddypodzolic soil amended with starch, wheat straw and alfalfa meal. Applied Soil Ecology 16:131-139.

Manilov AS, Dilly OM (2002). Soil microbial eco-physiology as affected by short term variations in environmental conditions. Soil Biology and Biochemistry 34:1283-1290.

Montagnini F, Haines B, Swank W (1989). Factors Controlling Nitrification in Soils of Early Succesional and Oak/Hickory Forests in the Southern Appalachians. Forest Ecology and Management 26:77-94.

Rusu M, Boeriu I, Vlăduțu I (1970). The activity of some ions from acid soils. Soil Science 6:26-32 (in Romanian).

Sandor M, Schrader S (2007). Earthworms affect mineralisation of different organic amendments in a microcosm study. Bulletin of University of Agricultural Sciences and Veterinary Medicine Cluj-Napoca. Agriculture 63/64:442-447.

Sandor M, Rusu M, Maxim A, Muntean E, Mihaiescu T, Toader C (2009). Nutrients Leaching from Soils with Different Functional Diversity Fertilized with Straw and Manure: an Experimental Approach. Bulletin of University of Agricultural Sciences and Veterinary Medicine ClujNapoca. Agriculture 66(2):210-215.

Stark C, Condron LM, Stewart A, Di HJ, O'Callaghan M (2007). Influence of organic and mineral amendments on microbial soil properties and processes. Applied Soil Ecology 35:79-93.

Sticht C, Schrader S, Giesemann A, Weigel HJ (2006). Effects of elevated atmospheric $\mathrm{CO}_{2}$ and $\mathrm{N}$ fertilization on abundance, diversity and C-isotopic signature of collembolan communities in arable soil. Applied Soil Ecology 34:219229.

Swift MJ, Izac AMN, Van Noordwijk M (2004). Biodiversity and ecosystem services in agricultural lanscapes-are we asking the right questions? Agriculture, Ecosystems and Environment 104:113-134. 